\title{
Deformation mechanisms in the frontal Lesser Himalayan Duplex in Sikkim Himalaya, India
}

\author{
Abdul Matin ${ }^{1}$ and Sweety Mazumdar ${ }^{2, *}$ \\ ${ }^{1}$ Department of Geology, University of Calcutta, 35 Ballygunge Circular Road, Kolkata 700 019, India. \\ ${ }^{2}$ Department of Geology, Presidency College, Kolkata 700 073, India. \\ e-mail: amatinindia@yahoo.com
}

\begin{abstract}
Understanding deformation mechanisms in Himalayan rocks is a challenging proposition due to the complex nature of the deformed rocks and their genesis. Crustal deformation in the Himalayan thrust belt typically occurs in elastico-frictional (EF) or quasi-plastic (QP) regimes at depths controlled mainly by regional strain-rate and geothermal gradient. However, material property, grain-size and their progressive changes during deformation are also important controlling factors. We present evidence of EF deformation from Gondwana rocks developed during the emplacement of one of the frontal horses (Jorthang horse) in the Lesser Himalayan Duplex (LHD) structure associated with Lesser Himalayan rocks in the footwall of the Ramgarh thrust in the Rangit window near Jorthang in the Sikkim Himalaya. The rocks in the horse exhibit systematic changes in microand meso-structures from an undeformed protolith to cataclasite suggesting that it was emplaced under elastico-frictional conditions. Meso- to micro-scale shear fractures are seen developed in Gondwana sandstone and slate while intercalated fine-grained shale-coal-carbonates are deformed by cataclastic flow suggesting that material property and grain-size have played an important role in the deformation of the Jorthang horse. In contrast, the hanging wall schists and quartzites of the Ramgarh thrust exhibit quasi-plastic deformation structures. This suggests that the Jorthang horse was emplaced under shallower crustal conditions than the antiformally folded Ramgarh thrust sheet even though the Ramgarh sheet presently overlies the Jorthang horse.
\end{abstract}

\section{Introduction}

Deformation in a mountain belt like the Himalaya is manifested over several different scales ranging from $1000 \mathrm{~km}$ to $<1 \mathrm{~km}$ (Mukul 2005). Understanding deformation mechanisms in Himalayan rocks is a challenging proposition due to the complex nature of the deformed rocks and their genesis. Sibson's (1977) conceptual model delineated two major deformational regimes (elastico-frictional (EF) and quasi-plastic (QP)) in quartzo-feldspathic Earth's crust in crustal-scale fault zone and the transition from EF to QP for a given grain-size depends on $\mathrm{P}-\mathrm{T}$ conditions, fluid content, rock type and strain rate. Crustal deformation in the Himalayan thrust belt, therefore, typically occurs in $\mathrm{EF}$ or $\mathrm{QP}$ regimes at depths controlled mainly by regional strain-rate and geothermal gradient.

The Lesser Himalayan Duplex (LHD) has been recognized in Darjiling-Sikkim Himalaya (Schwan 1980; Mukul 2002; Bhattacharyya et al 2006, 2008) and consists of horses involving Daling, Buxa and Gondwana rocks (figures 1 and 2). The frontal part of the LHD is exposed in the Rangit window (figure 2) through the overlying Ramgarh thrust

Keywords. Sikkim-Darjiling Himalaya; Rangit Window; north Kalijhora thrust; Ramgarh thrust; Lesser Himalayan Duplex; deformation mechanisms.

\footnotetext{
${ }^{*}$ Since deceased.
} 


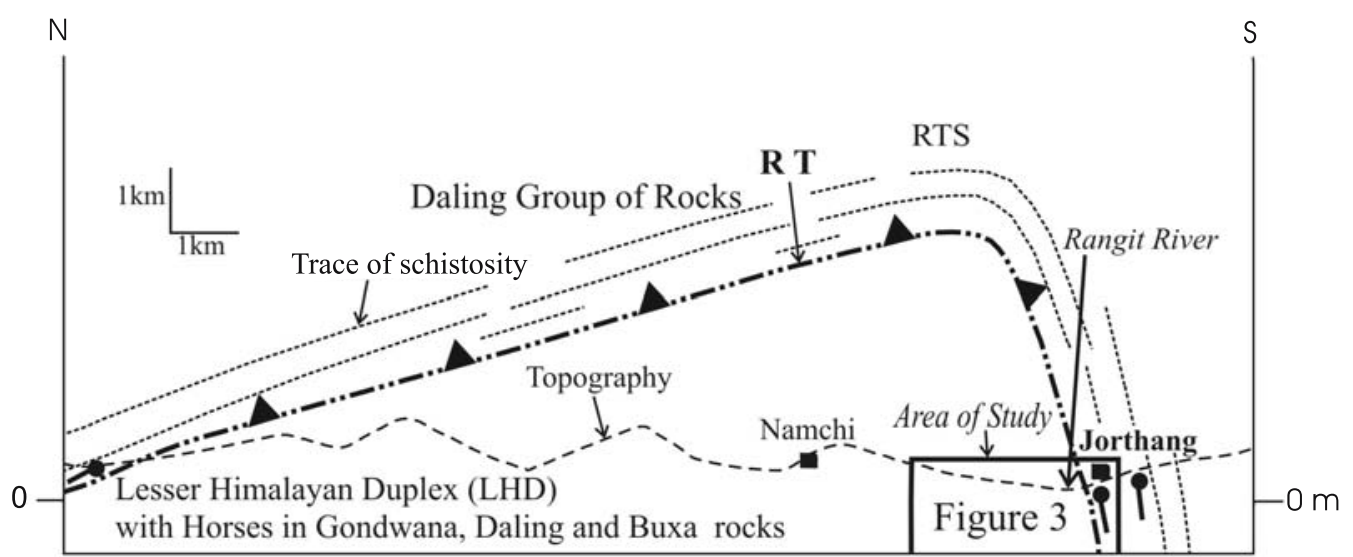

Figure 1. Schematic scaled vertical cross section across Rangit window from Rangit River in the south to north of Namchi showing large-scale antiformal structure in the hanging wall of Ramgarh thrust. RT, Ramgarh thrust; RTS, Ramgarh thrust sheet.

sheet (RTS) that consists of Proterozoic Daling group of rocks (figure 1). This fault was previously mapped as the Tendong thrust in the northern part of the Rangit window and as the Rammam-Rangit fault on the southern part of the window (Raina 1982). Given that the Ramgarh thrust elsewhere in the Himalaya (Valdiya 1980; Srivastava and Mitra 1994; DeCelles et al 2002; Pearson and DeCelles 2005) have similar structural position (footwall of the MCT thrusts) and transports a similar dominantly pelitic sequence in its hanging wall, we correlate the Tendong and Rammam-Rangit faults with the regionally recognized Ramgarh thrust. Similarly, the Ramgarh thrust can also be correlated with the north Kalijhora thrust (NKT) (Mukul 2000) in the frontal part of the Darjiling Himalaya as both faults carry the Daling sequence in their hanging wall and have Gondwana rocks of the MBT sheet in its footwall. The horses in the LHD exposed in the Rangit window involve the Daling, Buxa and the Gondwana units (Bhattacharyya et al 2008) and core an antiformal structure (Schwan 1980; Ray 2000) that folds the Ramgarh (figure 1) and the MCT sheets. The kinematics of the LHD is in the process of being worked out (Bhattacharyya et al 2008). We look at the deformation structures and mechanisms in the steep limb of the antiformal structure in the Ramgarh sheet and the Gondwana rocks of the frontal Jorthang horse in the LHD to understand the crustal conditions under which the structures are developed.

The macro- to grain-scale deformation structures (e.g., Newman and Mitra 1993; Srivastava and Sahay 2003 and references therein) described in this paper are seen developed in the Gondwana sandstone-shale-coal-carbonate rock association in the Jorthang horse of the LHD in the Rangit window of the Darjiling-Sikkim Himalaya (figures 1 and 2) just north of the Jorthang and around the Chisapani village (figure 3a). The aim of this paper is to study the Jorthang horse in detail and decipher the conditions under which the horse was emplaced and to compare that with the deformation conditions that existed during the emplacement of the now folded Ramgarh sheet.

\section{General geology}

The Himalayan orogen is wedge shaped and characterized by a basal detachment (Schelling and Arita 1991; Schelling 1992; Srivastava and Mitra 1994; Nelson et al 1996; Powers et al 1998; Mukul 2000; DeCelles et al 2002; Goscombe et al 2006 and references therein) and listric thrust faults that join the detachment at depth. Listric thrust faults and associated folds indicate that the frontal part of the wedge is a fold and thrust belt (FTB) (e.g., Schelling and Arita 1991; Schelling 1992; Srivastava and Mitra 1994; Powers et al 1998; Mukhopadhayay and Mishra 1999; Mukul 2000; Srivastava et al 2000; DeCelles et al 2002). The two major E-W trending thrusts in the Himalayan FTB are: the Main Central Thrust (MCT) and the Main Boundary Thrust (MBT). The MCT separates the Greater Himalayan Zone from the Lesser Himalayan Zone and the MBT separates the Lesser Himalayan Zone from the sub-Himalayan Zone (e.g., Hodges 2000; Yin 2006; and references therein). The Lesser Himalayan belt bounded between the MCT and MBT has experienced multiple phases of thrusting and duplex formation (e.g., Schelling and Arita 1991; DeCelles et al 2002). In this region, the Ramgarh thrust (Valdiya 1980; Srivastava and Mitra 1994; DeCelles et al 2002; Pearson and DeCelles 2005) is considered as a regional fault in the western and the Nepal Himalayas that has been locally recognized as 


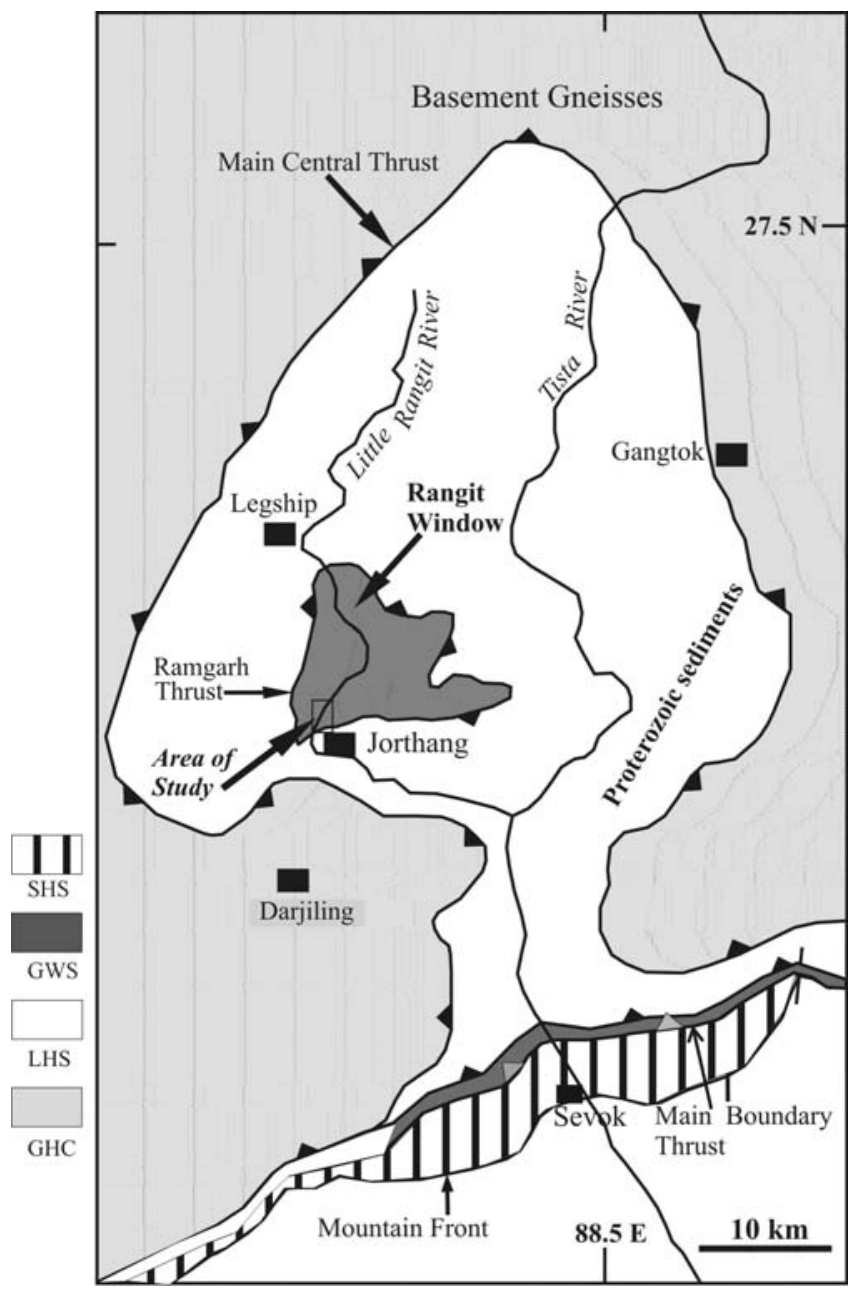

Figure 2. Tectonic map of the part of Darjiling-Sikkim Himalaya around Rangit window. GHC, Greater Himalayan crystalline complex; LHS, Lesser Himalayan sequence; GWS, Gondwana sequence; SHS, Sub-Himalayan sequence. Area of the present study is shown in box. Rangit window consists mainly of Gondwana horses with slices (horses) of Daling and Buxa rocks.

the north Kalijhora thrust in Darjiling-Sikkim Himalaya (Mukul 2000) and Shumar thrust in Bhutan Himalaya (McQuarrie et al 2008). It was mapped earlier as an unnamed fault (Sinha Roy 1967, 1974; Acharyya 1976, 1980; Schwan 1980). The Ramgarh thrust separates the PermoCarboniferous Gondwana (Gansser 1964) and also Daling and Buxa formations (Bhattacharyya et al 2008) in the LHD from the Proterozoic Daling Formation in the hanging wall (Heim and Gansser 1939; Gansser 1964; LeFort 1975). A spectacular tectonic window (Ghosh 1956; Raina 1982) is formed north of Jorthang. The Little Rangit River flows almost along the middle of the window (figure 2). The present area of study is located in one of the frontal horses of the LHD, which we name as Jorthang horse, and its adjacent area in the Ramgarh sheet located in the southwestern part of the Rangit window adjacent to the
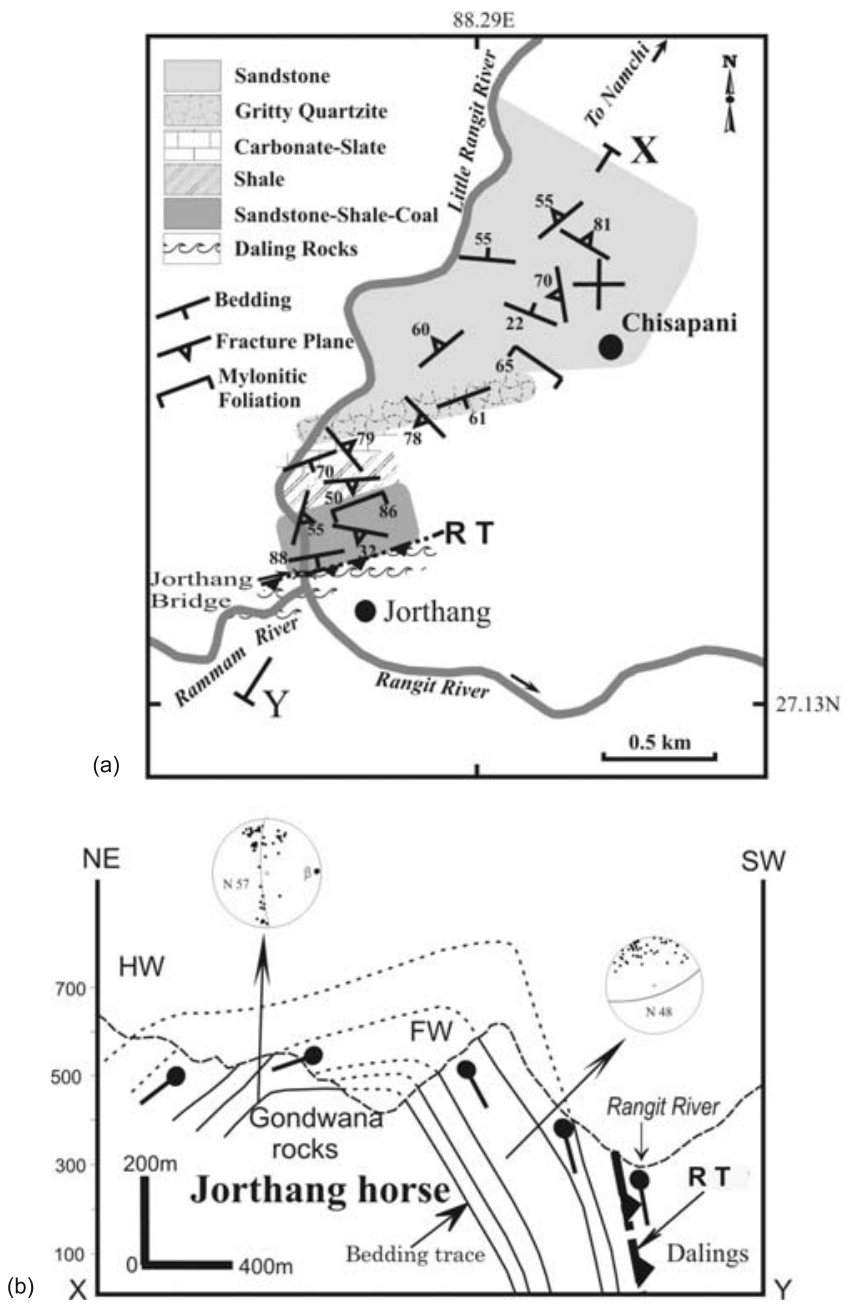

Figure 3. Large scale structure in Jorthang horse: (a) Geological map around Jorthang in Rangit window. $\mathrm{X}-\mathrm{Y}$ line of vertical cross section. (b) Vertical cross section along the line $\mathrm{X}-\mathrm{Y}$ (a) showing large-scale structure in the Jorthang horse in the footwall of Ramgarh thrust. RT - Ramgarh thrust, FW - footwall, HW - hanging wall of Ramgarh thrust. Stereographic projection of the poles of bedding in the gentle (north) and steep (south) limb of the antiformal structure in the horse (Gondwana rocks) are shown.

Ramgarh sheet, near the town of Jorthang, south Sikkim (figure 2).

\section{Large-scale structure}

The large-scale structure of the Rangit window has been deciphered as a regional antiform (Schwan 1980; Ray 2000) that has folded the Ramgarh and MCTs and their sheets; the MCT sheets have been eroded and only the Daling rocks of the Ramgarh sheet are presently preserved (figure 1). A transport parallel vertical section reveals a large-scale antiform (figure 1) with E-W axial trend that runs broadly parallel to the $\mathrm{E}-\mathrm{W}$ flowing Rangit River. The southern limb of the antiform is near vertical 


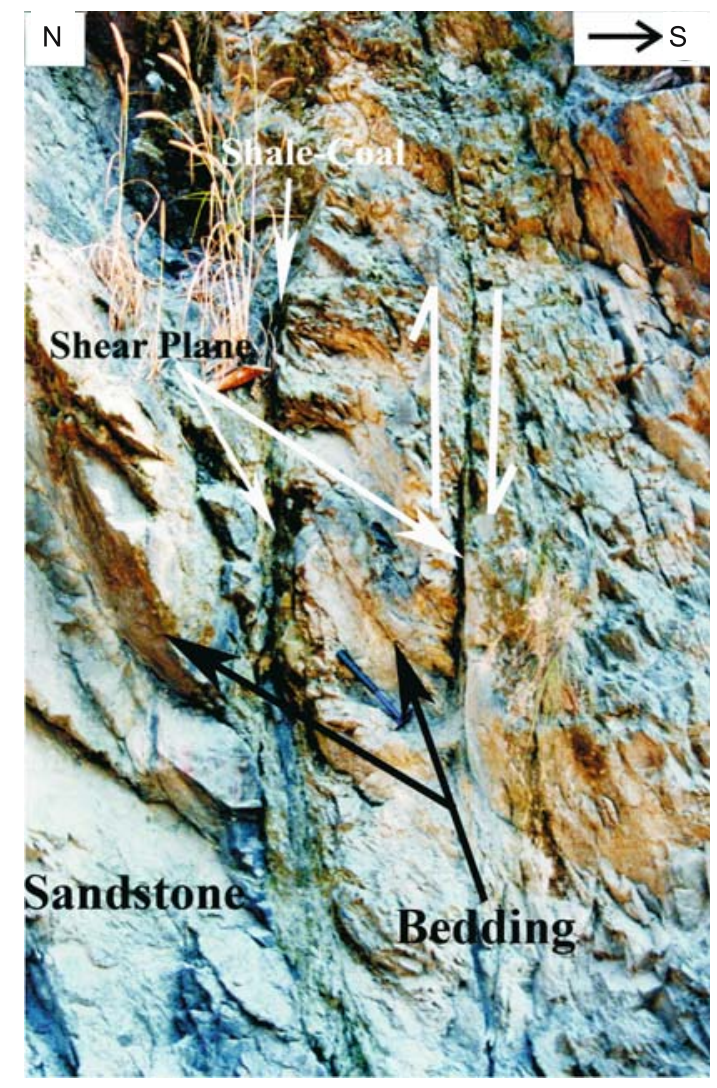

Figure 4. Vertical shear planes with s-c structure in the shale-coal unit. The right-hand block (south) moves down relative to the left-hand block (north). Bedding in sandstone dip steeply towards south making an acute angle with shear plane.

dipping steeply towards south. The northern limb dips gently towards north (figure 1). The fault zone related to the Ramgarh thrust is exposed in the river section near Jorthang. The mean orientation of the steep southern limb and gentle northern limb of the Jorthang antiform are $090^{\circ}, 77^{\circ} \mathrm{S}$ and $070^{\circ}$, $20^{\circ} \mathrm{NW}$ respectively (figure 1 ).

Detailed mapping was carried out along a transport parallel N-S section to study the Jorthang horse located in the immediate footwall of the steeply dipping southern limb of the folded Ramgarh thrust (figure 3a). The Jorthang horse shows an antiformal structure (figure $3 \mathrm{~b}$ ); the bedding planes in the gentle northern limb have been folded into a number of broad open $\mathrm{E}-\mathrm{W}$ trending folds while in the southern limb the bedding planes are steeply dipping southward (figure 3b). The mean orientation of bedding of the steep southern limb is $071^{\circ}, 73^{\circ} \mathrm{SE}$ (figure $3 \mathrm{~b}$ ), bedding plane poles in the gentle northern limb are distributed on a well-defined girdle suggesting that the bedding planes have been folded to cylindrical folds with the fold axis $(\beta)$ plunging $09^{\circ} \rightarrow 087^{\circ}$ (figure $3 \mathrm{~b}$ ). The rocks in the steep limb are strongly sheared with near vertical to vertical shear planes developed at a low angle to bedding in sandstone and shale (figure 4). The shear planes are developed in the coal-shale bands intercalated with the sandstone unit. In the coalshale unit the rocks exhibit cataclastic flow along the shear plane that defines a well developed foliation in the fault zone. Small fist-sized pods and bands of 'horses' consisting of highly fractured sandstone are occasionally present within the outcrop-scale shear zone. The shear planes are closely spaced, usually less than a meter (figure 4); the spacing depends on the spacing of the coalshale intercalated units. The shear planes are curved (figure 4) and occasionally anastomosing in nature. The mean orientation of the shear plane is $145^{\circ}, 85^{\circ} \mathrm{SW}$ with variation in dip is between $78^{\circ}$ and $90^{\circ}$. The intensity of the development of the shear plane is maximum near the Ramgarh thrust.

\section{Deformation features}

\subsection{Ramgarh thrust sheet}

The Daling Formation in the hanging wall of the Ramgarh thrust is mainly made up of greyish green phyllites and quartzites and purple phyllite with massive quartzite bands. Dalings are intricately folded and metamorphosed to lower greenschist facies.

The Daling group of rocks exposed in the two limbs of the large-scale antiform of the Ramgarh sheet consists of chlorite phyllite and schist intercalated with thin (less than a $\mathrm{cm}$ ) to thick (a few metres) quartzite bands and lenses. The quartzite bands are often folded to small-scale folds of variable geometry and orientations. All structures are quasi-plastic with no signature of elasticofrictional deformation. The dominant planar fabric is represented by secondary compositional banding of alternate silica-rich and phyllosilicate-rich bands (figure 5a) and schistosity/phyllitic cleavage. They are axial planar to an earlier unidentifiable folded penetrative fabric. Pressure solution cleavage (figure 5b) is also well developed parallel to the main foliation plane specially in the phyllosilicaterich part of the schist (figure 5b). They are thin, dark, wavy sub-parallel seams with variable spacing in micro-scale (figure 5b). In the microlithon part the crenulation of an earlier fabric is seen (figure $5 \mathrm{~b}$ ); the pressure solution planes are axial planar to the crenulation (figure $5 \mathrm{~b}$ ). In the quartzrich part the pressure solution planes are short, discontinuous and incipiently developed (figure $5 \mathrm{~b}$ ). The compositional banding as well as the dominant schistosity have been microfolded (figure 5a) and micro-crenulation is developed in the hinge 

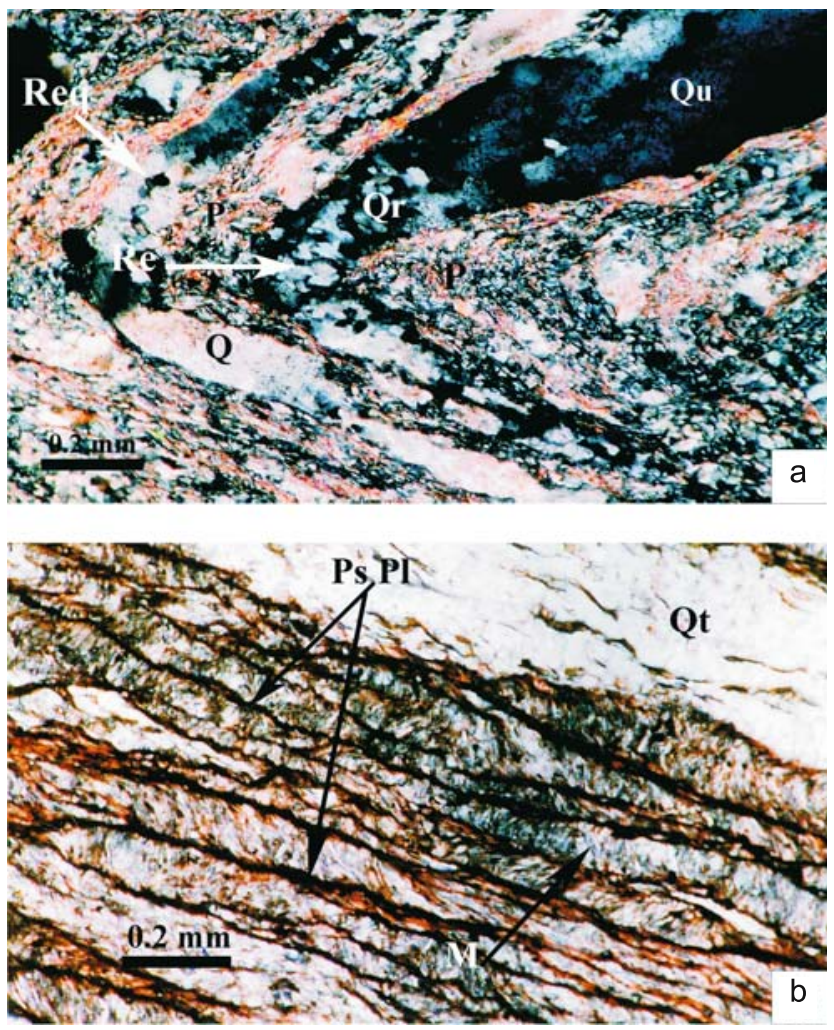

Figure 5. (a) Photomicrograph of Daling schist showing microfolded secondary compositional banding defined by alternate silica-rich (Q and Qr) and phyllosilicate-rich (P) bands. Quartz grains in quartz-rich bands show undulose extinction $(\mathrm{Qu})$ and partially recrystallized to elongate (Re) and equigranular-polygonal grains (Req). Phyllosilicate bands are micro-crenulated in the hinge zone (arrow adjacent to Re) of the microfold. (b) Photomicrograph of Daling schist showing micro-crenulation of earlier fabric in the phyllosilicate-rich microlithons (M) and development of wavy pressure solution planes ( $\mathrm{Ps} \mathrm{Pl}$ ) parallel to the axial plane of micro-crenulation. In the quartz-rich band (Qt, top left) only discrete solution planes (dark wavy seams) are developed.

zone in the phyllosilicate-rich layer of the microfold (figure 5a). The quartz grains in the silica-rich bands show strong undulose extinction and also partially recrystallized to small polygonal to elongated grains (figure 5a). The dominant foliation has almost completely transposed an earlier fabric. It is not clear from microstructures whether the earlier planar fabric is a deformational or a primary sedimentary/diagenetic structure. The dominant planar fabric later acted as a plane of movement during shearing resulting in a phyllonitic foliation. This phyllonitic foliation has been folded along with the Ramgarh sheet by the large-scale regional antiform. The youngest decipherable event in these rocks consists of transverse broad warps with near vertical N-S to NNE-SSW striking axial plane marked by spaced cleavage.

All the observed deformation microstructures in the Daling rocks are the result of deformation under quasi-plastic conditions. In fine grained phyllite, phyllosilicates and fine grained quartz grains show alignment thereby defining the dominant schistosity in the rock. Pressure solution has also played a major role in the deformation process as evident from pressure fringes, fibrous growth or 'whiskers' of mica as well as wavy pressure solution cleavage (figure 5b) that show anastomosing and branching patterns. The end result of the development of pressure solution and crenulation cleavage is a fabric consisting of alternate domains of folded earlier fabric and secondary cleavage (figure 5b). At places the earlier fabric is completely transposed by the later foliation. Shearing along planes at very low angle to the main foliation is also seen at places. The quartz grains in the quartzrich domains show intracrystalline deformation features such as undulose extinction, deformation lamellae and recrystallization at elevated temperature (figure 5a) (Passchier and Trouw 2005). Grain-scale recovery structures such as deformation bands, subgrains formation and recrystallization (figure 5a) are also seen in these quartz grains.

\section{Jorthang horse}

\subsection{Lithology}

The important rocks in the Jorthang horse are Gondwana sandstone, shale, coal, impure carbonate and gritty quartzite (figure 3a). The sandstone is brown coloured, fine-to-coarse grained, poorly sorted, texturally and mineralogically immature, massive to well-bedded with thickness of the beds varying from a few centimeters to a meter with local micro-lamination. Clasts consist of fine-tomedium sand-sized quartz grains $(\sim 95 \%$ of total clast volume), variable amount of angular to rounded partly altered plagioclase feldspar $(<5 \%)$ and opaque minerals and occasional thin and long flakes of biotite and muscovite and rock fragments of quartzite, granite, slate and chert. The size of the clasts varies from $\sim 0.2-\sim 0.9 \mathrm{~mm}$, except the shale fragments which are up to $\sim 3 \mathrm{~mm}$ long. The matrix and cement (recrystallized to sericite) constitute about $5-10 \%$ of the total rock volume. The texture is framework supported clastic texture but locally matrix is higher $(>15 \%)$ forming matrix supported texture. Gritty quartzite consists of grits of quartz along with fragments of shale, which have no preferred orientation. The framework consists of quartz $(\sim 60 \%)$, altered feldspar $(\sim 30 \%)$ and rock fragments $(\sim 10 \%)$ of chert and quartzite and rarely biotite and garnet. The recrystallized matrix and cement constitute about $15 \%$ by volume of the rock. The texture is usually matrix supported and locally clast supported. 


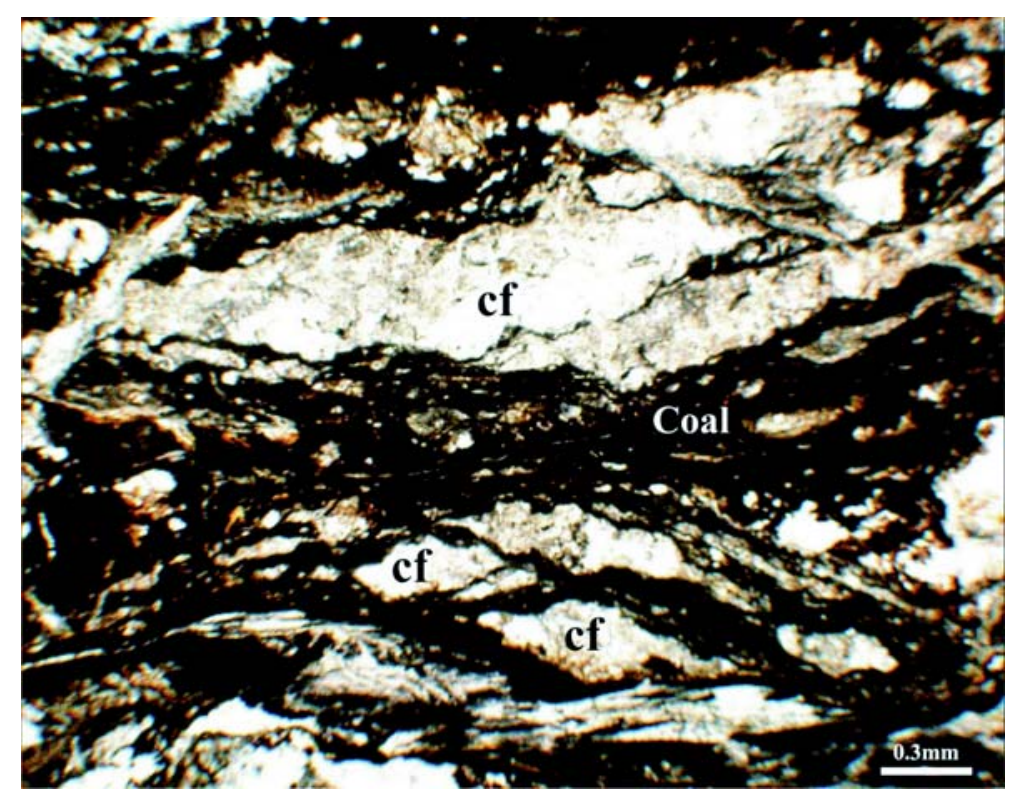

Figure 6. Photomicrograph of foliation in coal. Cataclastic fragments of siliceous materials (cf., light colour) of different shapes and sizes are dimensionally oriented parallel to the foliation. Fine cataclastic fragments embedded in coal (black colour) flow along with coal during cataclastic flow. Plane polarized light.

Shale is distinctly laminated, grey to greenish grey to black in colour with the thickness of individual shale beds varying from $10 \mathrm{~cm}$ to $2 \mathrm{~m}$. Shale has been transformed to slate adjacent to the Ramgarh fault zone. Slate is composed of very finegrained quartz, chlorite and sericite.

Intercalations of coal lenses and bands of a few $\mathrm{cm}$ to $\sim 1.6 \mathrm{~m}$ thickness occur within shale and sandstone. Thin laminated carbonate bands intercalated with slate consist mainly of fine-grained, equidimensional to elongated carbonate grains with subordinate opaque minerals, chlorite and quartz. Multiple generations of quartz veins are present.

In sandstone and shale, cohesive cataclastic rocks are developed in narrow zones separated by incipiently deformed rocks in an island-channel mode of spatial distribution. The signature of cataclasis is seen in outcrop-to-micro-scale but the textural details can only be seen under the microscope.

\subsection{Structure}

\subsubsection{Small-scale structure}

Important planar and linear structures are bedding, slaty cleavage and fracture planes; linear structures include fold axis lineation and kinks and slickenlines. Foliation related to cataclastic flow is seen in coal-shale unit (figure 6) and in carbonates. Fracture planes are ubiquitously developed in sandstone (figure 3a). Three conjugate sets of fracture planes (sets A, B and C) are noted which are developed in the same locality. These are sharp fracture planes that slice the sandstone into $2-5 \mathrm{~cm}$ thick microlithons (figure $7 \mathrm{a}$ ). In slate, conjugate kink bands (figure 7b) and small-scale folds are occasionally developed. The axial plane of the small-scale folds are parallel to the fracture plane in sandstone. Parallelism of the kink bands in slate with the fractures in sandstone suggests the latter to be conjugate shear fractures. The fracture sets are probably developed in the late phase of the deformation history because it cross-cuts all earlier fabric in the rocks. The conjugate set A is the most dominant. The stereographic projections, mean orientation and angle between the conjugate sets of the fracture planes are plotted (figure 8). The smaller-scale fractures in sandstones are neither uniformly distributed, nor uniformly oriented, on the scale of the exposure and in hand samples; the cataclastic rocks almost always give the impression of having an isotropic cataclastic fabric. The width of the fractures ranges between $1 \mathrm{~mm}$ and a few $\mathrm{mm}$ and their length is from a few centimeters to tens of centimeters.

Polished slickenside planes with slickenlines and steps (figure 9) indicating top-to-the-south thrust motion is present in sandstone on the northern gentler limb of the antiform developed in the Jorthang horse. Mineral fibers or slickenfibres, oriented parallel to the slickenlines (figure 9) are defined by the coarse fibres of quartz that appear to grow with their long axes parallel to the prevailing direction of fault displacement. Slickensides in shale and slate are generally small. Dark anastomosing micro-scale $(\sim 0.01-\sim 0.1 \mathrm{~mm})$ solution planes 

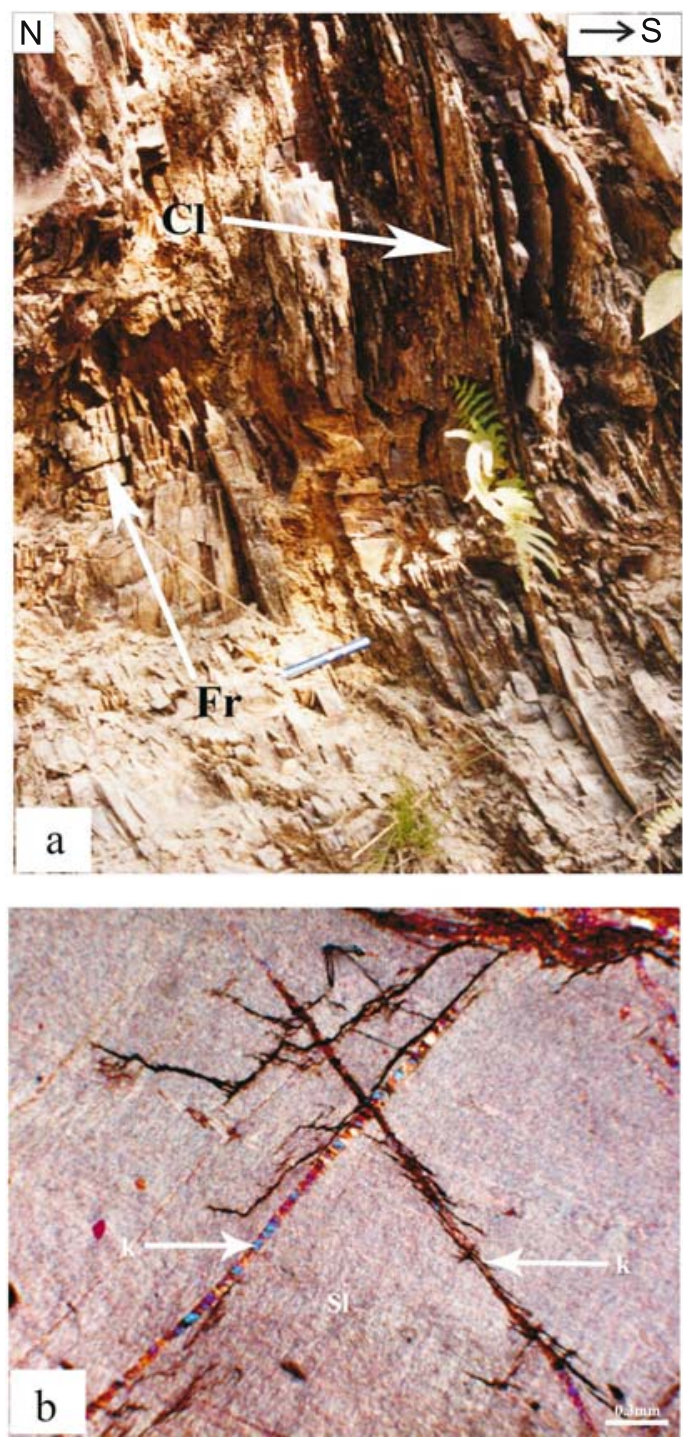

Figure 7. (a) Gondwana sandstone-shale sequence with one set sub-horizontal close-spaced fracture plane (Fr), bedding and bedding parallel sub-vertical slaty cleavage $(\mathrm{Cl})$ near Jorthang bridge. (b) Photomicrograph of conjugate set kink folds in slate $(\mathrm{Sl})$. Kink bands (k) are partially replaced by silica. Between cross polars with gypsum plate.

often occur as thin straight or curved seams in slate and sandstone (figure 10). Shear planes in coalshale unit are present in the southern steep limb of the antiform present in the Jorthang horse near the Ramgarh fault zone (figure 4). Bedding parallel shear planes are developed in shale-carbonate intercalations; in the carbonate bands sharp shear fractures are often developed at an acute angle to bedding. Fold axis lineations of broad warps and kink folds (figure $7 \mathrm{~b}$ ) are occasionally observed in slates and carbonates. Ridge-in-groove lineations or fault mullions is observed in sandstone.

Small-scale folds are rare, best developed in the carbonate rocks and are occasionally observed in slates and sandstones in the northern limb of the antiform. In carbonate rocks small-scale folds are asymmetric, non-plunging to gently plunging, $\mathrm{E}-\mathrm{W}$ trending and are dextral in section looking from west suggesting top-to-the-south movement, that is, in conformity with the southward emplacement of the Jorthang horse. The outcrop-scale folds in the impure carbonates are expressed as folded microbands in thin sections. A strong preferential alignment of the deformed elongated carbonate and opaque grains define axial planar foliation to these microfolds. Carbonate veins that parallel and cross cut the axial planar structures to the microfolds are also present.

Extensive silicification is seen in sandstone as well as in slate in the Jorthang horse. Numerous thin quartz veins of less than a millimeter to a few centimeters thick are present that occasionally show pinch and swell structure, fold and microfaulting. Earlier formed quartz veins are folded, and are often cross-cut by later veins (figure 10). The apparent displacement of quartz veins are seen along pressure solution seams (figure 10).

\subsubsection{Microstructure}

Thin sections of samples from the Jorthang horse as well as the Ramgarh fault zone were cut approximately along the N-S transport plane. Microstructures from the sandstones within the Jorthang horse reveal that most of the deformation occurred at shallow crustal levels within the elastico-frictional (EF) regime (Sibson 1977). However, the fine-grained carbonate and coal-shale intercalated units in the horse exhibit cataclastic flow.

\subsubsection{Microstructures formed in sandstone}

The Gondwana sandstones deformed in the Jorthang horse are dominantly framework supported sandstone rocks with grains varying from coarse to fine in size. Thin sections of these sandstones reveal that the clasts are surrounded by a matrix of comminuted material and secondary minerals. The clast-in-matrix texture can be subdivided into cataclastic and granular textures (cf., Twiss and Moores 1992). Gouge is formed locally with finer $(<0.1 \mathrm{~mm})$ clast size which is essentially a continuation of the breccia series to finer clasts size (cf., Twiss and Moores 1992; Paschier and Trouw 2005) with occasional few large isolated fragments surrounded by finer matrix. Cataclastic or EF deformation mechanisms include grain crushing, abrasion, intergranular frictional sliding along grain boundaries, rotation of grain fragments, and growth of a network of micro-cracks sometimes straight and sometimes less regular (figure 11a). A variety of different crack geometries, morphologies and orientations are developed 


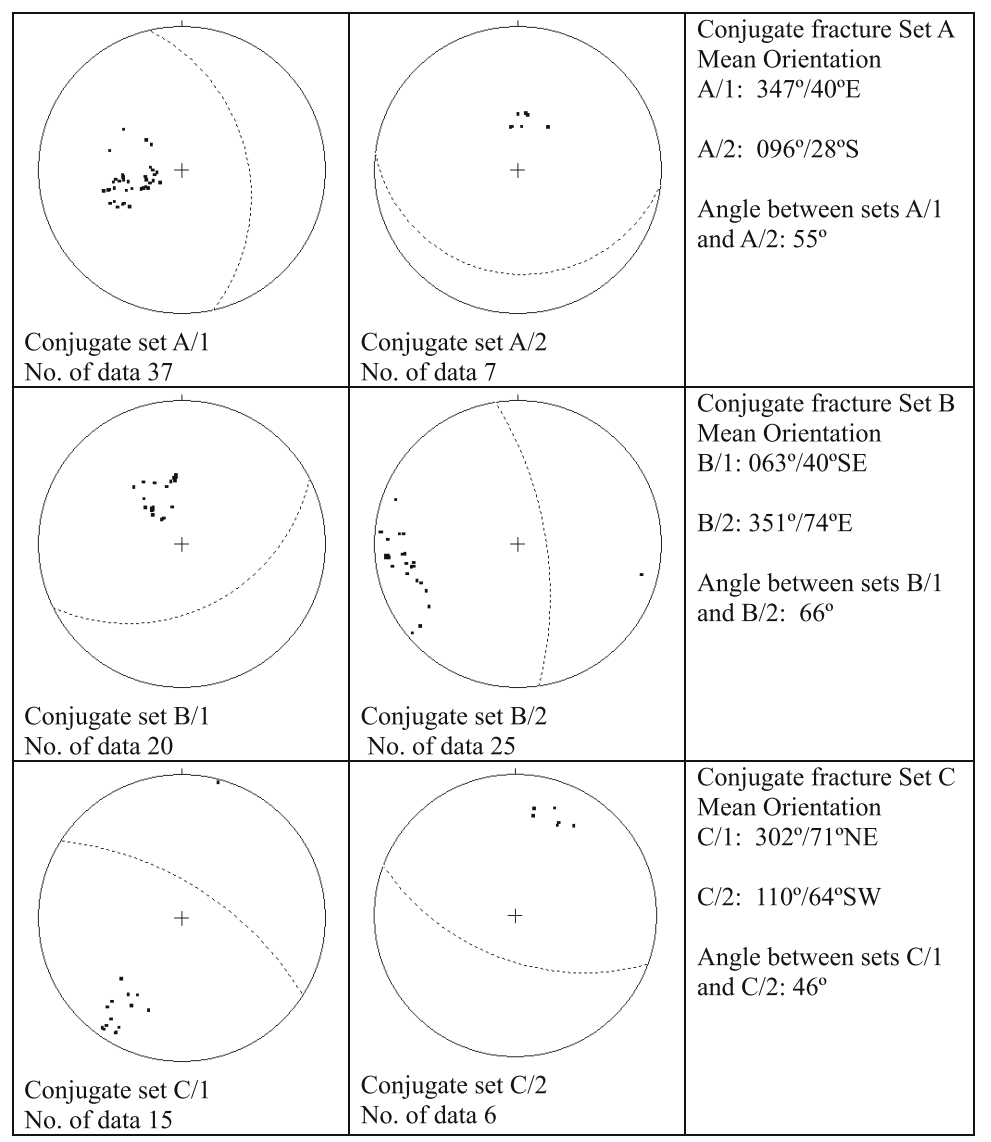

Figure 8. Stereographic projection of fracture sets A, B and C.

in the sandstone. The cracks may be broadly divided as intragranular cracks and intergranular cracks (Kranz 1983) or transgranular fracture (Paschier and Trouw 2005). Intragranular cracks are confined within single grains and die out either within the grains or at the grain boundaries (figure 11b). The microfractures die out within a short distance (intragranular crack) or continue for a long distance as grain boundary or transgranular cracks (figures 11a, b, c, d and 12a), and branch out at places. Fracture density varies from grain to grain (figure 11a). The micro-cracks may be unhealed or healed cracks (figures 11c, 12a). Large biotite flakes are also fractured to develop intragranular and transgranular shear cracks suggesting that the biotite also behaved in an EF manner in the deformation regime (figure 11d).

Intragranular cracks typically end at grain boundaries (figure 11b) or within the grain (figures $11 \mathrm{c}$ and $\mathrm{d}$ ) either because they run into a more ductile matrix or because they impinge on a grain with a suitably oriented glide system that allows the stress concentration to be dissipated (Mitra 1978). Other intragranular cracks that form during fracturing under EF conditions are developed only in grains that are optimally oriented to the deforming stress (Ismat and Mitra

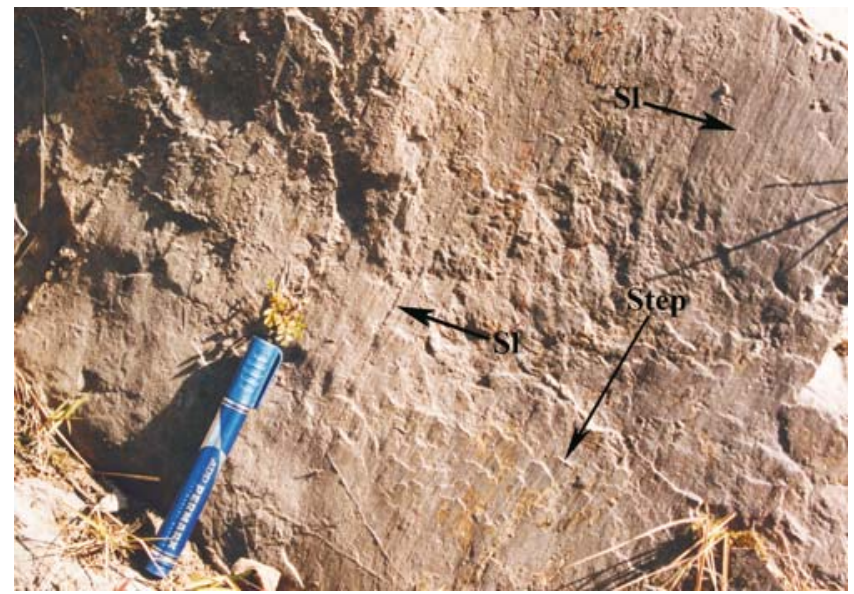

Figure 9. Slickenside with slickenline in sandstone. Quartz fibre parallel to the slickenline $(\mathrm{Sl})$ and steps (shown by arrow) facing in one direction are oriented normal to the slickenline (Sl).

2001). Intragranular cracks in the same orientation in many grains suggest that they are brittle and result from far-field stresses that also produced the large transgranular cracks (figure 11a). Intergranular cracks range in length from a few grain diameters to throughgoing fractures in the rock. They generally form under EF deformation conditions 


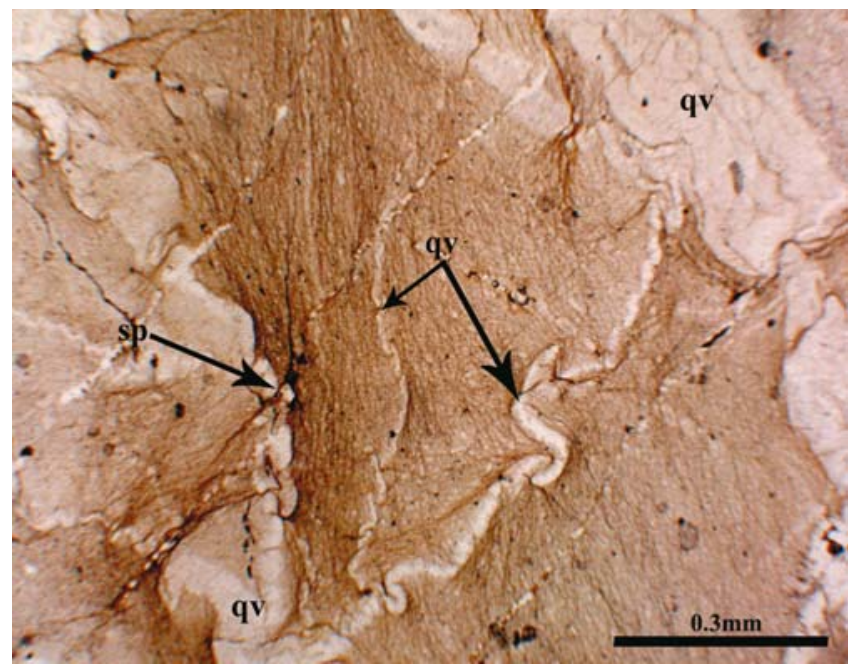

Figure 10. Photomicrograph of folded quartz veins (qv, light-coloured). The fold geometry varies from irregular to regular. Fine pressure solution planes (sp) are marked by thin dark seams along which the silica veins show apparent displacement. Plane polarized light. under which cracks, once nucleated, can coalesce with other cracks through propagation due to stress concentration at crack tips.

Wider transgranular zones of fine-grained cataclasite, which completely reformed the original grains, show microstructures resembling sintered material (Anderson et al 1974). Extremely finegrained (approximately $1 \mu \mathrm{m}$ in size) materials of the reformed grains show interlocking grain boundaries (figure 11a). Because of their fine grain-size and three dimensional interlocking nature the boundaries often appear a little fuzzy under the microscope (figure 11a). There are very thin $(0.1 \mathrm{~mm}$ to $0.3 \mathrm{~mm})$ zones of cemented cataclasite that cross-cut the early foliation. There are also thick $(0.5 \mathrm{~mm}$ and more) sintered microzones (figure 11a) of cemented cataclasite with angular, randomly oriented fragments that probably grew from thinner zones by incorporating angular fragments from the wall rock into the zones (figure 11a).
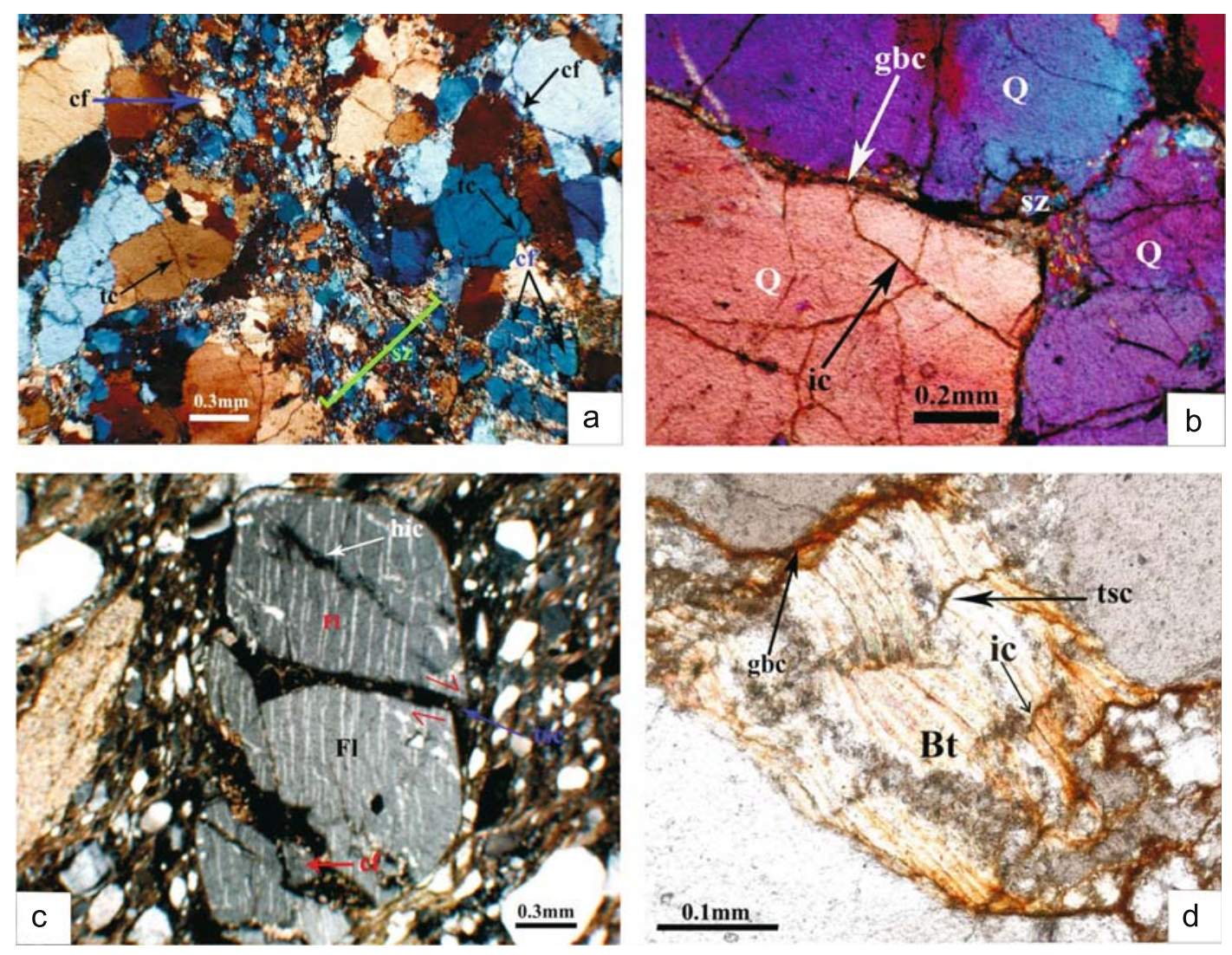

Figure 11. Microscale structures in sandstone: (a) Photomicrograph of narrow sintered zone (sz) with irregular boundaries, consists of cataclastic fragments (cf) of different shapes and sizes. The grains in both the walls of the sintered zone (sz) show intergranular cracks (tc) with variation of fracture density from grain to grain. Between cross polars with gypsum plate. (b) Photomicrograph of clast supported sandstone with grain boundary crack (gbc) and intragranular crack (ic). The cracks show iron oxide staining. Small sintered zone (sz) is produced at the junction of three grains. Between cross polars with gypsum plate. (c) Photomicrograph of large fractured feldspar clast (Fl) with healed intragranular crack (hic), healed transgranular shear crack (tsc) and clast fragment (cf) between cross polars. (d) Photomicrograph of transgranular (tsc), grain boundary (gbc) and intragranular (ic) shear cracks in large biotite clast (Bt) in sandstone. The cleavage trace of the biotite clast is sheared along the transgranular shear crack (tsc). Between cross polars. 
Sandstone grains, however, also show quasiplastic deformation microstructures such as undulose extinction (figure 12a) and deformation bands and lamellae (Paschier and Trouw 2005). Local subgrain formation and incipient recrystallization (figure 12a) are also observed in quartz grains within the sandstones. However, the EF deformation microstructures are seen to overprint the QP structures and are more dominant in the Gondwana sandstones in the Jorthang horse. This suggests that although the Jorthang horse was emplaced under shallow crustal EF conditions, the sandstone in the horse was subjected to an earlier QP deformation event.

\subsubsection{Microstructures formed in slate}

The Gondwana slates in the Jorthang horse typically exhibit slaty cleavage. Clasts of slatefragments of different shapes and sizes are observed to be embedded in secondary siliceous material; the clasts are deformed and commonly fractured along the cleavage. The slates are often crushed to form extensively silicified ultracataclasite (figure 12b) in which randomly oriented slate clasts vary in length from $1.4 \mathrm{~mm}$ to $3.2 \mathrm{~mm}$ and in width from $1.2 \mathrm{~mm}$ to $2.5 \mathrm{~mm}$ and the shapes vary from almost equant with highly irregular and angular boundaries (figure 12b) to fine short needles. The size of the largest clasts in the ultracataclasite is up to $4.5 \mathrm{~mm}^{2}$. Some of the slate clasts are elongate in shape (figure 12b). Intergranular and intragranular shear cracks developed in the slate fragments often follow the cleavage planes (figure 12b). The clasts are embedded in siliceous matrix with quartz veins cut across the earlier matrix (figure 12b).

\subsubsection{Microstructures formed in coal-shale and limestone}

Evidence of cataclastic flow is observed in coalshale unit and in carbonate rocks that are intercalated with the sandstone and slate units. In the fine grained coal-shale unit shear fabric has developed due to the flow of coal (figure 6). Under the microscope the coal bands appear to be wavy and swerve around the porphyroclasts of siliceous material. The siliceous rock fragments are usually lens-shaped, preferentially oriented parallel to the foliation plane (figure 6). In mesoscopic scale the foliation appears as continuous bands (figure 4).

Fine grained carbonate bands occur as intercalations within other units. Micro-scale folds are developed with axial planar foliation defined by deformed carbonate and opaque minerals. Locally micro-shear bands are developed in carbonate-slate intercalated rocks. The shear bands are closely spaced, commonly sub-parallel, but also branching
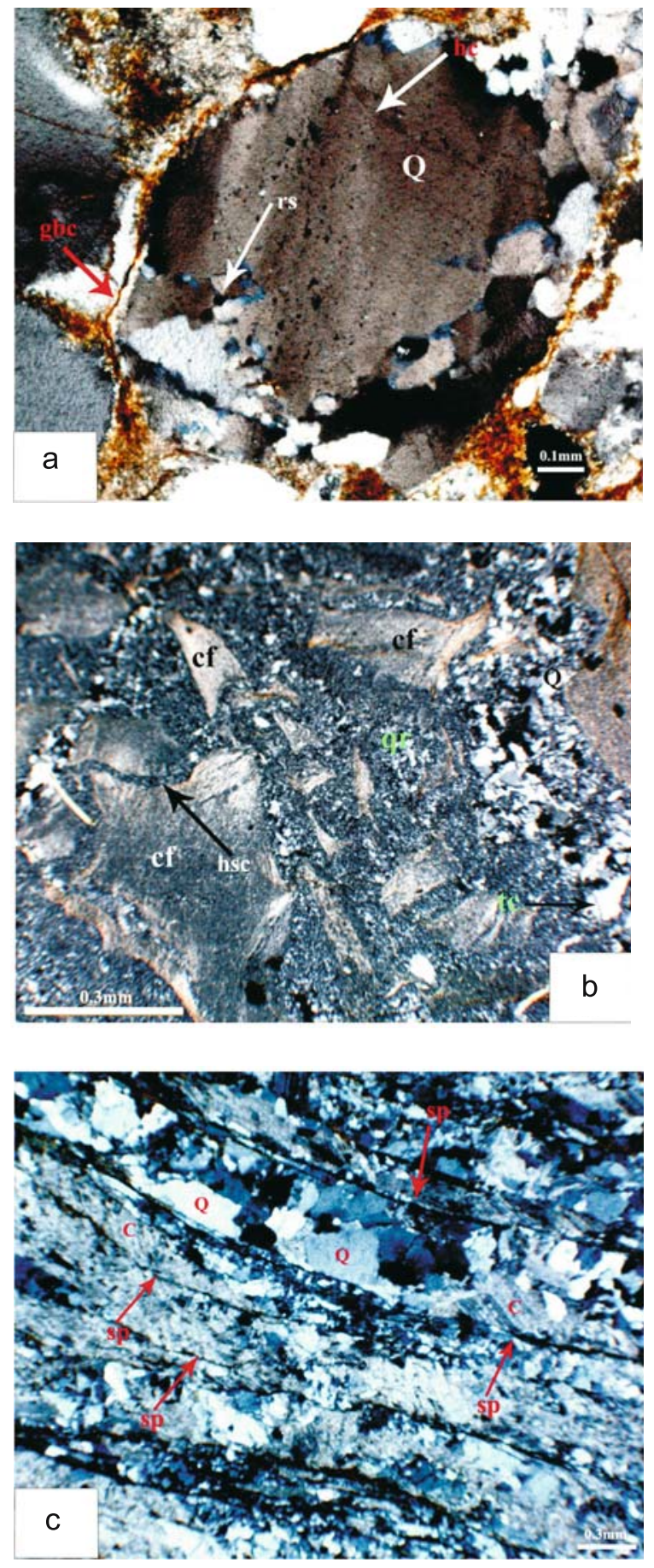

Figure 12. Microscale structures: (a) Photomicrograph of large strained quartz grain with undulose extinction and healed crack (hc). Locally the strained quartz grain (Q) is incipiently recrystallised (rs). Grain boundary crack (gbc) is present with iron oxide staining. Between cross polars. (b) Photomicrograph of ultracataclasite slate shows randomly oriented clasts of slate (cf) of varying shape and size in a matrix of recrystallized quartz (qr). Quartz vein (Q) cuts across the earlier recrystallized quartz matrix. Healed intergranular shear cracks (hsc) are present in slate clasts. Transgranular crack (tc) is visible in some quartz grains of the vein quartz. Between cross polars. (c) Photomicrograph of close-spaced shear fabric (sp) in carbonate rock. The carbonate rock is extensively silicified (Q). Carbonate grains (C) show secondary twin lamellae oriented at acute angle with the shear plane. Between cross polars. 
or coalescing and extensively silicified (figure 12c). In the carbonate grains secondary twinning has developed; the secondary twin planes are oriented at an acute angle $\left(\sim 45^{\circ}\right)$ with the shear planes.

The material properties of coal-shale and carbonate units are obviously different from those of sandstone and slate. Moreover, the coal-shale and carbonate units are very fine grained. Given this the coal-shale and carbonate units deformed by cataclastic flow in contrast with sandstone and slate that fracture and form cohesive cataclasite.

\section{Deformation mechanisms}

Elastico-frictional deformation mechanisms were predominantly active in the Jorthang horse. Fractures and cataclasite were typically formed during the EF deformation. Cracking and frictional sliding were typically active during the EF deformation and produced zones of comminuted material. The cohesiveness of the cataclastic material indicates somewhat greater depths of $\sim 4-15 \mathrm{~km}$. The influx of fluids in the form of silica and opaque oxides suggest dilatancy. In the sandstone-shale-coal cataclastic rocks microcracks and fractures indicate cataclasis in which brittle fracturing controlled the deformation process in the formation of cataclasites and gouges. Evidence for crystal plastic deformation has been found locally; however, it is clearly of subordinate importance, and brittle fracturing was dominant and overprinting the QP deformation microstructures. Mechanical twinning in carbonate grains may have also formed during this earlier QP phase. Pressure solution involving dissolution of material from high-stress locations and precipitation at lower stress sites is present in sandstones of the Jorthang horse. The process operates at moderately shallow levels of the crust at around $200^{\circ}-300^{\circ} \mathrm{C}$ (Snoke et al 1998).

The coal-shale unit and the carbonate rocks within the fault zone show evidence of cataclastic flow with the development of cleavage. It appears that material property and grain size dependent deformation mechanism played a major role in the EF deformation of the Gondwana rocks of the Jorthang horse.

The deformation mechanisms in the hanging wall Daling rocks of the Ramgarh sheet is dominated by low to moderate temperature QP deformation. No evidence of EF deformation structures are observed in the Ramgarh sheet rocks.

\section{Conclusion}

The zone between the MCT and MBT in Darjiling Sikkim Himalaya is characterized by the formation of Lesser Himalayan Duplex (LHD). The horses in the LHD have been exposed through a physiographic Rangit window through an antiformal structure that has folded the Ramgarh and the MCT sheets.

The Ramgarh sheet rocks were deformed exclusively in QP regime with no signature of brittle deformation. Gondwana rocks were deformed in the Jorthang horse which is one of the frontal horses in the LHD duplex. The Gondwana rocks in the Jorthang horse are deformed dominantly in the EF regime that overprints earlier signatures of QP deformation in these rocks. Therefore, there is a stark contrast in the nature of deformation in the rocks of the Ramgarh sheet and the Jorthang horse. This suggests that EF deformation dominated the emplacement of Jorthang horse in the LHD. Given that the Ramgarh sheet rocks exposed in the southern limb of the large-scale antiform exhibit only QP deformation microstructures it seems likely that the emplacement of the Jorthang horse occurred at a late stage in the development of LHD when the overburden above the Jorthang horse was lesser even though the Ramgarh sheet rocks currently overlie the Jorthang horse rocks.

\section{Acknowledgements}

The first author (AM) condoles the untimely death of Sweety Mazumdar (second author) who died in a road accident in USA where she was pursuing her higher studies. The authors are grateful to the three anonymous reviewers for their critical review and valuable suggestions. We benefited from discussions with Ananda Chakraborty. We are immensely grateful to the Associate Editor of JESS for the support received during the processing and revision of the paper.

\section{References}

Acharyya S K 1976 On the nature of the Main Boundary Fault in the Darjiling Sub-Himalaya; Geol. Surv. India Misc. Publ. 24 395-408.

Acharyya S K 1980 Structural framework and tectonic evolution of the eastern Himalaya; Tenth annual seminar on Himalayan Geology, J. Himalayan Geol. 10 412-439.

Anderson J C, Leaver K D, Alexender J M and Rawlings R D 1974 Materials Science; Van Nostrand Reinhold, UK.

Bhattacharyya K, Mitra G and Mukul M 2006 The Geometry and Implication of a Foreland Dipping Duplex, The Rangit Duplex, Darjiling-Sikkim Himalayas, India; Geological Society of America Abstracts with Programs 38(7) 413.

Bhattacharyya K, Mitra G and Mukul M 2008 The Geometry and Kinematics of the Darjeeling - Sikkim Himalaya, India; Geological Society of America Abstracts with Programs $\mathbf{4 0 ( 6 )} 549$. 
DeCelles P G, Robinson D M and Zandt G 2002 Implications of shortening in the Himalayan fold-thrust belt for uplift of the Tibetan Plateau; Tectonics 211062.

Gansser A 1964 The Geology of the Himalayas (New York: Interscience Publishers) $289 \mathrm{pp}$.

Ghosh A M N 1956 Presidential address in the 43rd Indian Science Congress, Geology and Geography Branch; Proc. Ind. Sci. Congr. 38 Sess.

Goscombe B, Gray D and Hand M 2006 Crustal architecture of the Himalayan metamorphic front in eastern Nepal; Gondwana Res. 10 232-255.

Heim A and Gansser A 1939 Central Himalaya, geological observations of Swiss expedition 1936; Mem. Soc. Helv. Sci. Nat. 73(1) 245 pp.

Hodges K V 2000 Tectonics of the Himalaya and southern Tibet from two perspectives; Bull. Geol. Soc. America $112324-350$.

Ismat Z and Mitra G 2001 Microfracturing associated with reactivated fault zones and shear zones; what can it tell us about deformation history? In: The nature and tectonic significance of fault zone weakening (eds) Holdsworth, Robert E et al, Geol. Soc. Spec. Publ. 186 113-140.

Kranz R L 1983 Microcracks in rock: A review; Tectonophys. $100449-480$.

LeFort P 1975 Himalayas - collided range - present knowledge of continental arc; Amer. J. Sci. A275 1-44.

McQuarrie N, Robinson D, Long S, Tobgay T, Grujic D, Gehrels G and Ducea M 2008 Preliminary stratigraphic and structural architecture of Bhutan: Implications for the along strike architecture of the Himalayan system; Earth Planet. Sci. Lett. 272 105-117.

Mitra G 1978 Ductile deformation zones and mylonites: The mechanical processes involved in the deformation of crystalline basement rocks; Amer. J. Sci. 278 1057-1084.

Mukhopadhyay D K and Mishra P 1999 A balanced crosssection across the Himalayan foreland belt, the Punjab and Himachal foothills: A reinterpretation of structural styles and evolution; Proc. Indian Acad. Sci. (Earth Planet. Sci.) 108(3) 189-205.

Mukul M 2000 The geometry and kinematics of the Main Boundary Thrust and related neotectonics in the Darjiling Himalayan Fold-and-Thrust belt, West Bengal, India; J. Struct. Geol. 22 1261-1283.

Mukul M 2002 The kinematics of neotectonics in the Darjeeling-Sikkim-Tibet (DaSiT) Himalayan Wedge: Abstracts, International Conference on Quaternary Climate, Tectonics and Environment of the Himalaya: Comparison with Other Regions, March 11-15, 2002, 126-127.

Mukul M 2005 Continental Deformation and Global Positioning System based Geodesy; Himalayan Geology 26(1) 193-198.

Nelson K D and twenty-six others 1996 Partially molten middle crust beneath Southern Tibet: Synthesis of project INDEPTH results; Science 274 1684-1696.

Newman J and Mitra G 1993 Lateral variations in fault zone thickness as influenced by fluid-rock interactions,
Linville Falls fault, North Carolina; J. Struct. Geol. 15 849-863.

Pearson O N and DeCelles P G 2005 Structural geology and regional tectonic significance of the Ramgarh thrust, Himalayan fold-thrust belt of Nepal; Tectonics $\mathbf{2 4}$ TC4008.

Passchier C W and Trouw R A 2005 Microtectonics (New York: Springer) $366 \mathrm{pp}$.

Powers P M, Lillie R J and Yeats R S 1998 Structure and shortening of the Kangra and Debra Dun reentrants, subHimalaya, India; Geol. Soc. Amer. Bull. 110 1010-1027.

Raina V K 1982 The Rangit Tectonic Window - Stratigraphy, Structure \& Tectonic Interpretation and its Bearing on the Regional Stratigraphy; Geol. Surv. India Misc. Publ. 41(Part II) 36-42.

Ray S K 2000 Culmination Zones in Eastern Himalaya; Geol. Surv. India Misc. Publ. 55 85-94.

Schelling D 1992 The tectonostratigraphy and structure of the eastern Nepal Himalaya; Tectonics 11 925-943.

Schelling D and Arita K 1991 Thrust tectonics, crustal shortening, and the structure of the far-eastern Nepal, Himalaya; Tectonics 10 851-862.

Schwan W 1980 Shortening Structures in Eastern and North-western Himalayan Rocks; (ed.) Saklani P S, Today and Tomorrow's Printers and Publishers, New Delhi.

Sibson R H 1977 Fault rocks and fault mechanics; J. Geol. Soc. London 133 191-213.

Sinha Roy S 1967 Tectonic evolution of the Darjeeling Himalayas; Quart. J. Geol. Mining Metallurgical Soc. India 48 167-178.

Sinha Roy S 1974 Tectonic elements in the Eastern Himalaya and geodynamic model of evolution of the Himalaya; Geol. Surv. India Misc. Publ. 34 57-74.

Snoke A, Tullis W J and Todd R 1998 Fault related rock: A photographic atlas (Princeton: Princeton University Press) 717 pp.

Srivastava H B, Sahai A and La1 S N 2000 Strain and Crystallographic Fabric in Mesoscopic Ductile Shear Zones of Garhwal Himalaya; Gondwana Res. 3 395-404.

Srivastava D C and Sahay A 2003 Brittle tectonics and pore-fluid conditions in the evolution of the Great Boundary Fault around Chittaurgarh, Northwestern India; J. Struct. Geol. 25 1713-1733.

Srivastava P and Mitra G 1994 Thrust geometries and deep structure of the outer and Lesser Himalaya, Jumoan and Garhwal (India): Implications for evolution of the Himalayan fold and thrust belt; Tectonics 13 89-109.

Twiss R J and Moores E M 1992 Structural Geology; (New York: W H Freeman and Company) 532 pp.

Valdiya K S 1980 Geology of the Kumaun Lesser Himalaya; The Himachal Press, Wadia Institute of Himalayan Geology, Dehradun, 219 pp.

Yin A 2006 Cenozoic tectonic evolution of the Himalayan orogen as constrained by along-strike ariation of structural geometry, exhumation history, and foreland sedimentation; Earth Sci. Rev. 76 1-131. 